Reviu Akuntansi dan Bisnis Indonesia, Vol. 5 No. 2, Hlm 122-137, Desember 2021

Website: http://journal.umy.ac.id/index.php/rab

\title{
Peran Akuntabilitas sebagai Moderasi Hubungan Religiusitas dan Literasi Wakaf terhadap Minat Berwakaf Uang
}

\author{
Dinda Adistii; Dewi Susilowati; Permata Ulfah \\ Program Studi Akuntansi Universitas Jenderal Soedirman
}

\section{N F O A R T I K E L}

\section{Kata Kunci:}

Religiusitas; Literasi Wakaf; Akuntabilitas; Minat; Wakaf Uang

Jenis Artikel:

Penelitian Empiris

\section{Korespondensi:}

dinda.adistii@mhs.unsoed.ac.id

\section{Proses Artikel:}

Diterima 5 Juli 2021

Review 5 Agustus 2021

Revisi 11 Oktober 2021

Revisi 4 November 2021

Diterbitkan Desember 2021

\section{Sitasi:}

Adistii, D., Susilowati, D., \&

Ulfah, P. (2021). Peran

akuntabilitas sebagai moderasi

hubungan religiusitas dan

literasi wakaf terhadap minat

berwakaf uang. Reviu Akuntansi

dan Bisnis Indonesia, 5(2), 122-

137.

Link Artikel:

10.18196/rabin.v5i2.12238

\section{A B S T RAK}

\section{Latar Belakang:}

Data Badan Wakaf Indonesia (BWI) tahun 2019 menunjukkan bahwa negara Indonesia memiliki potensi aset wakaf per tahun mencapai $\mathrm{Rp} 2.000$ triliun dengan luas tanah wakaf mencapai 420 ribu hektare. Sementara potensi wakaf uang di Indonesia dalam setahun mencapai $\mathrm{Rp} 77$ triliun namun pengumpulan yang terealisasi hanya sebesar Rp 185 miliar atau hanya 0,24\% dari potensinya. Rendahnya realisasi potensi wakaf uang juga mencerminkan rendahnya minat masyarakat yang tentunya disebabkan oleh berbagai macam faktor. Oleh karena itu, penelitian ini bertujuan untuk meneliti lebih lanjut faktor-faktor yang diduga berpengaruh terhadap minat berwakaf uang.

\section{Tujuan:}

Penelitian ini bertujuan untuk menganalisis dan memprediksi pengaruh religiusitas dan literasi wakaf terhadap minat berwakaf uang serta menganalisis dan memprediksi peran akuntabilitas dalam memoderasi pengaruh religiusitas dan literasi wakaf terhadap minat berwakaf uang.

\section{Metode Penelitian:}

Populasi pada penelitian ini ialah anggota grup WaCIDS dan NoCAFE Unsoed, dengan pemilihan sampel dilakukan menggunakan metode convenience sampling, sehingga diperoleh sampel 100 responden. Data yang diperoleh dianalisis menggunakan teknik analisis regresi linear berganda dan analisis regresi moderasi.

\section{Hasil Penelitian:}

Hasil penelitian ini menunjukkan bahwa: (1) Religiusitas berpengaruh positif terhadap minat berwakaf uang; (2) Literasi wakaf berpengaruh positif terhadap minat berwakaf uang; (3) Akuntabilitas tidak dapat memoderasi hubungan antara religiusitas dengan minat berwakaf uang; (4) Akuntabilitas dapat memoderasi hubungan antara literasi wakaf dengan minat berwakaf uang.

\section{Keterbatasan Penelitian:}

Penelitian ini memiliki beberapa keterbatasan, yaitu: (1) Penelitian ini dilakukan pada dua grup diskusi wakaf yaitu WaCIDS dan NoCAFE yang anggotanya sudah mengenal wakaf, (2) Penelitian ini hanya berfokus pada wakaf uang. Berdasarkan keterbatasan tersebut, penelitian selanjutnya diharapkan dapat meneliti minat berwakaf uang pada masyarakat umum sehingga bisa merepresentasikan minat berwakaf uang secara umum. Dan penelitian selanjutnya diharapkan dapat meneliti minat berwakaf jenis lain seperti cash waqf link sukuk, wakaf hewan, dan lainnya.

\section{Keaslian/Novelty Penelitian:}

Penelitian terkait wakaf masih terus berkembang, khususnya tentang wakaf uang. Dan penelitian ini memberikan diskusi baru dengan menggunakan variabel dan indikator yang berbeda dari penelitian terdahulu. 


\section{PENDAHULUAN}

Indonesia merupakan negara dengan jumlah penduduk yang besar. Pada Juni 2020, Indonesia tercatat memiliki penduduk sebanyak 268.583.016 jiwa. Dari penduduk sebanyak itu, Indonesia memiliki jumlah penduduk miskin sebanyak 26,42 juta jiwa atau sebesar 9,78\% tercatat pada bulan Maret 2020. Tingkat kemiskinan yang tinggi tentunya memiliki dampak yang besar terhadap masyarakat baik di bidang ekonomi, pendidikan, kesehatan, dan lainnya (Badan Pusat Statistik, 2020). Dilihat dari World Giving Index oleh Charities Aid Foundation bulan Oktober 2018, Indonesia menjadi negara dengan tingkat kedermawanan yang tinggi dengan skor 59\%. Sebanyak $46 \%$ masyarakat Indonesia dinilai bersedia menolong orang asing, sebanyak $78 \%$ suka berdonasi dalam bentuk uang, dan sebanyak 53\% masyarakat Indonesia bersedia menjadi sukarelawan (Winahyu, 2019). Selain itu, populasi muslim di Indonesia mencapai 87\% (Pew Researcher Center, 2020). Hal ini merupakan suatu peluang yang bisa digunakan sebagai salah satu solusi pengentasan kemiskinan dengan cara membantu sesama.

Islam memiliki ibadah yang manfaatnya dapat dirasakan bersama yaitu ibadah Zakat, Infaq, Shodaqoh, dan Wakaf (Ziswaf). Manfaat dari Ziswaf, khususnya manfaat dari wakaf bisa digunakan untuk membantu masyarakat miskin Indonesia. Wakaf menjadi salah satu instrumen yang bisa dimanfaatkan bukan hanya untuk sisi kebutuhan pokok masyarakat miskin, namun bisa dimanfaatkan untuk mendukung bisnis masyarakat miskin yang bersifat berkelanjutan atau jangka panjang (Munadiyan, 2020).

Atas dasar data Badan Wakaf Indonesia (BWI) tahun 2019, negara Indonesia memiliki potensi aset wakaf per tahun mencapai Rp 2.000 triliun dengan luas tanah wakaf mencapai 420 ribu hektare. Sementara potensi wakaf uang di Indonesia dalam setahun mencapai $\mathrm{Rp} 77$ triliun namun pengumpulan yang terealisasi hanya sebesar $\mathrm{Rp} 185$ miliar atau hanya $0,24 \%$ dari potensinya (Winahyu, 2019). Wakaf uang ialah wakaf yang dilakukan oleh seseorang, sekelompok orang, dan lembaga atau badan hukum dalam bentuk uang (Nurhayati \& Wasilah, 2016:334). Tabel 1 dibawah ini adalah tabel perbandingan antara potensi wakaf uang di Indonesia dengan realisasinya.

Tabel 1 Potensi \& Realisasi Wakaf Uang

\begin{tabular}{cccc}
\hline Tahun & Potensi Wakaf (Rp) & Realisasi (Rp) & Persentase (\%) \\
\hline 2019 & 77.000 .000 .000 .000 & 185.000 .000 .000 & 0,2403 \\
2020 & 180.000 .000 .000 .000 & 391.000 .000 .000 & 0,2172 \\
2021 (Januari) & 180.000 .000 .000 .000 & 819.360 .000 .000 & 0,4552 \\
\hline
\end{tabular}

Sumber: Badan Wakaf Indonesia (2021)

Tabel 1 di atas dapat dilihat bahwa penghimpunan wakaf di Indonesia masih sangat jauh dari potensi yang ada. Rendahnya minat berwakaf uang di masyarakat ditunjukkan dengan perbandingan realisasi dan potensi wakaf uang dalam beberapa tahun terakhir. Realisasi yang tidak mencapai $1 \%$ ini sangatlah miris mengingat besarnya potensi wakaf uang yang ada dan fakta bahwa 87\% masyarakat Indonesia ialah muslim. Rendahnya realisasi potensi wakaf uang juga mencerminkan rendahnya minat masyarakat yang tentunya disebabkan oleh berbagai macam faktor. Oleh karena itu, penelitian ini bertujuan untuk meneliti lebih lanjut faktor-faktor yang diduga berpengaruh terhadap minat berwakaf uang.

Dalam Theory of Planned Behavior oleh Ajzen (1991) menganggap minat sebagai faktor yang memotivasi individu dalam berperilaku. Minat untuk memberikan wakaf uang dalam penelitian Fauziah dan El Ayyubi (2019) menunjukkan bahwa masih banyak masyarakat yang belum memiliki pengetahuan dan pemahaman tentang wakaf yang baik. Para wakif cenderung memberikan wakaf hanya berpedoman pada aspek religiusitas dan kebiasaan. Penelitian Hiyanti dkk. (2020); AsShadiqqy (2019); Amalia dan Puspita (2018) menunjukkan bahwa religiusitas menjadi faktor yang mempengaruhi minat dalam wakaf uang. Namun dalam penelitian Cupian dan Najmi (2020); Fauziah dan El Ayyubi (2019) menunjukkan hasil bahwa religiusitas tidak berpengaruh terhadap minat dalam wakaf uang. 
Data menunjukkan bahwa Nilai Indeks Literasi Wakaf (ILW) Indonesia tergolong dalam kategori rendah, yaitu dengan skor 50,48. Skor ini diperoleh dari hasil survey BWI di 32 provinsi dengan 100 responden tiap provinsinya atau 3200 responden di seluruh Indonesia. Nilai ini terdiri dari Nilai Literasi Pemahaman Wakaf Dasar sebesar 57,67 dan Nilai Literasi Pemahaman Wakaf Lanjutan sebesar 37,97 (Badan Wakaf Indonesia, 2020). Penelitian Cupian dan Najmi (2020), Fauziah dan El Ayyubi (2019); dan Mokthar (2016) menunjukkan bahwa literasi wakaf menjadi faktor yang berpengaruh terhadap minat dalam wakaf uang.

Minat masyarakat terhadap wakaf uang juga tidak terlepas dari peran lembaga wakaf contohnya dari segi akuntabilitasnya. Berdasarkan Theory of Planned Behavior, minat seseorang dapat dipengaruhi oleh persepsi kontrol perilaku. Persepsi ini dapat terbentuk karena informasi-informasi yang diterima. Persepsi seseorang terhadap akuntabilitas lembaga wakaf dapat mempengaruhi keputusan dalam berwakaf uang. Sejalan dengan penelitian dalam bidang zakat oleh Salmawati dan Fitri (2018) dan Assagaf (2016), menyimpulkan bahwa akuntabilitas berpengaruh positif terhadap minat muzakki dalam membayar zakat. Faktor akuntabilitas ini diduga bisa menjembatani variabelvariabel penelitian seperti religiusitas dan literasi wakaf. Dalam hal religiusitas, seseorang yang memiliki tingkat religiusitas tinggi dan juga mengetahui akuntabilitas lembaga wakaf akan merasa semakin yakin untuk melakukan wakaf uang. Hal ini juga berlaku pada literasi wakaf, saat seseorang memiliki tingkat literasi wakaf yang tinggi dan didukung dengan mengetahui akuntabilitas lembaga wakaf maka minat seseorang tersebut dalam wakaf uang bisa meningkat.

\section{TINJAUAN LITERATUR DAN PERUMUSAN HIPOTESIS}

\section{Theory of Planned Behavior}

Teori yang mendasari penelitian ini ialah Theory of Planned Behavior (TPB). Teori ini menjelaskan bahwa manusia bertindak sesuai dengan minat dan persepsi mereka, sedangkan sikap (evaluasi melakukan suatu perilaku), norma subjektif (tekanan sosial yang dirasakan dan harapan untuk melakukan atau tidak melakukan suatu perilaku), dan kontrol perilaku yang dirasakan (persepsi kemudahan atau kesulitan melakukan suatu perilaku) mempengaruhi minat (Ajzen, 1991). TPB menjelaskan faktor-faktor yang mempengaruhi minat seseorang, yaitu:

1. Sikap Terhadap Perilaku (Attitude Toward Behavior)

Sikap terhadap perilaku dapat didefinisikan sebagai perasaan positif atau negatif individu dalam melakukan suatu perilaku. Sikap terhadap perilaku umumnya lebih berpengaruh terhadap minat dibandingkan dimensi norma subyektif dan persepsi kontrol perilaku. Dari berbagai studi yang berbeda tentang perilaku dan minat, sikap terhadap perilaku menjelaskan lebih dari 50\% dari varian minat (Ajzen, 1991). Sehingga semakin positif sikap, semakin tinggi minatnya (Osman dkk., 2016).

2. Norma Subyektif (Subjective Norm)

Norma subyektif ialah tekanan sosial yang dirasakan untuk terlibat dalam suatu perilaku. Hal ini diasumsikan bahwa norma subyektif ditentukan oleh sekumpulan keyakinan normatif yang dapat diakses mengenai harapan referensi penting (Ajzen, 1991).

3. Persepsi Kontrol Perilaku (Perceived Behavior Control)

Persepsi kontrol perilaku mengacu pada persepsi individu tentang kemampuan mereka dalam melakukan suatu perilaku (Osman dkk., 2016).

\section{Wakaf}

Wakaf diatur dalam Peraturan Pemerintah Tentang Pelaksanaan Undang -Undang Nomor 41 Tahun 2004 Tentang Wakaf. Wakaf adalah perbuatan hukum pemberi wakaf (wakif) untuk menyisihkan sebagian dananya atau menyerahkan hartanya guna pemanfaatan jangka panjang atau jangka waktu tertentu sesuai dengan kepentingannya dalam tujuan ibadah dan/atau kesejahteraan 
umum menurut syariah. Ada 6 rukun wakaf yang dijelaskan dalam Undang-Undang Nomor 41 Tahun 2004 Tentang Wakaf, antara lain: pemberi wakaf (al-waqif), barang yang diwakafkan (almauquf), penerima wakaf (mauquf 'alaih), ikrar/akad (sighah) wakaf, pengelola wakaf (nazhir), dan jangka waktu.

Wakaf uang secara umum memiliki beberapa manfa'at antara lain (Prasinanda \& Widiastuti, 2019):

1. Menumbuhkan jiwa sosial. Kemudahan dan tanpa batasan minimal wakaf uang membuat semua kalangan masyarakat dapat melakukan wakaf uang dan meningkatkan jiwa sosialnya.

2. Mengurangi kesenjangan sosial. Dana wakaf uang yang dikelola dan disalurkan dapat meningkatkan kesejahteraan sosial ekonomi penerima wakaf.

3. Pahala wakaf tidak terputus meski wakif telah meninggal dunia. Seperti sabda Rasulullah Shalallahu 'alaihi wassalam yang mengatakan jika seseorang meninggal dunia, maka terputuslah amal perbuatannya, kecuali tiga hal; yakni sedekah jariyah, ilmu yang bermanfaat, dan doa anak yang shaleh (HR. Muslim, Imam Abu Daud, dan Nasa'iy) dan jumhur ulama sepakat bahwa yang dimaksud sedekah jariyah salah satu bentuknya ialah wakaf (Nurhayati \& Wasilah, 2019: 284).

\section{Wakaf Uang}

Wakaf uang diatur dalam Peraturan Menteri Agama RI No. 4 Tahun 2009 Tentang Wakaf Uang. Wakaf uang ialah perbuatan hukum pemberi wakaf (wakif) untuk menyisihkan/menyerahkan sebagian uang miliknya guna pemanfaatan jangka panjang atau jangka waktu tertentu sesuai dengan kepentingannya dalam tujuan ibadah dan/atau kesejahteraan umum menurut syariah. Wakaf uang memiliki skema pengelolaan yang berbeda dibandingkan wakaf jenis lainnya. Di Indonesia, pengelolaan wakaf uang berada di bawah pengawasan Kementerian Agama. Pengelolaan wakaf uang juga diatur oleh BWI selaku regulator sekaligus pengelola wakaf (nazhir), lembaga wakaf (nazhir), dan Lembaga Keuangan Syariah Penerima Wakaf Uang (LKS PWU). LKS PWU bertugas melakukan penghimpunan dan penerimaan wakaf uang dari waqif kemudian diberikan kepada nazhir selaku pengelola. Agar dana tersebut berkelanjutan, nazhir mengelola dan menginvestasikannya. Hasil dari investasi tersebut sebagian besar disalurkan kepada mauquf 'alaih dan sebagian kecil akan digunakan nazhir sebagai penunjang proyek wakaf selanjutnya (Kementerian Keuangan Republik Indonesia, 2019).

\section{Religiusitas}

Religiusitas merupakan suatu kondisi pada diri seseorang yang mendorongnya dalam bertingkah laku sesuai dengan tingkat kepatuhannya terhadap agama. Religiusitas merupakan tindakan yang sumbernya berasal langsung atau tidak langsung kepada Nash (Jalaludin, 2001: 89). Religiusitas meliputi pengetahuan tentang agama, pengalaman ritual agama, moralitas agama, dan sikap sosial keagamaan yang diterapkan (Abou-Youssef dkk., 2011). Sedangkan menurut Rizal dan Amin (2017) mengatakan bahwa religiusitas mengacu pada keyakinan seseorang kepada Tuhan dan sejauh mana mereka mengikuti jalan yang Tuhan tetapkan.

\section{Literasi Wakaf}

Literasi wakaf adalah kemampuan dalam memahami dan mengelola wakaf yang aman, berkelanjutan, dan bermanfaat (Kementerian Agama Republik Indonesia, 2017). Sedangkan menurut Baskoroputra (2019) literasi wakaf merupakan kemampuan individu dalam menerima, mengolah, dan memahami informasi wakaf. Literasi wakaf dapat disimpulkan dalam lima verba, yaitu memahami, melibati, menggunakan, menganalisis, dan mengubah teks. Direktorat Pemberdayaan Zakat dan Wakaf Kementerian Agama RI, Pusat Kajian Strategis Badan Amil Zakat (Puskas BAZNAS), dan Badan Wakaf Indoensia (BWI) telah menyusun suatu alat ukur yang digunakan untuk mengukur secara akurat tingkat pemahaman masyarakat terhadap zakat dan wakaf. Alat ukur ini disebut dengan Indeks Literasi Zakat dan Wakaf (ILZW) yang didalamnya terdapat indikator-indikator zakat dan wakaf yang bisa merepresentasikan pemahaman zakat dan wakaf masyarakat dengan akurat. 


\section{Akuntabilitas}

Akuntabilitas merupakan suatu keharusan dalam melaporkan dan bertanggung jawab atas kesuksesan ataupun kegagalan dalam pencapaian tujuan organisasi melalui media pertanggungjawaban yang dibuat secara periodik (Mardiasmo, 2009: 20). Akuntansi menjadi hal penting dalam wakaf karena akad wakaf menyatakan bahwa aset wakaf yang diberikan oleh pemberi wakaf (waqif) harus dikelola oleh lembaga wakaf (nazhir). Dengan kata lain, akuntansi menjadi sarana untuk melaksanakan akuntabilitas lembaga wakaf. Aset wakaf yang ditujukkan untuk kemaslahatan umum membuat lembaga wakaf memiliki ruang lingkup pertanggungjawaban yang berbeda dari perusahaan pada umumnya. Lembaga wakaf harus bertanggung jawab kepada berbagai pihak seperti waqif, regulator, penerima manfaat, dan masyarakat luas (Ihsan \& Ibrahim, 2011). Menurut Ibrahim (2000), akuntabilitas lembaga wakaf dapat dijelaskan sebagai akuntabilitas kepada Allah dan akuntabilitas kepada manusia. Dan manajemen lembaga wakaf yang baik dapat dikelola sesuai dengan prinsip Good Organization Governance (Sholahuddin, 2006), yaitu melalui aspek amanah, transparansi, dan profesional.

\section{Minat}

Zusnani (2013) menjelaskan bahwa minat ialah suatu ketertarikan mendalam yang disertai dengan perasaan senang atas suatu hal sehingga menimbulkan tindakan atas dasar keinginan sendiri. Minat dapat disebabkan oleh faktor internal maupun eksternal. Minat mendasari seseorang dalam berperilaku, sehingga minat yang kuat akan menyebabkan seseorang bersemangat dalam melakukan hal yang diminati dalam hal ini minat berwakaf uang. Crow and Crow dalam Shaleh dan Wahab (2004), menjelaskan tiga faktor timbulnya minat yaitu: faktor dorongan dari dalam, faktor motif sosial, dan faktor emosional.

\section{Pengaruh Faktor Religiusitas Dalam Mempengaruhi Minat Berwakaf Uang}

Seseorang dapat dikatakan religius ketika menguasai atau menjalani kehidupannya sesuai dengan lima dimensi religiusitas, yaitu dimensi pengalaman, dimensi ritualistik, dimensi ideologis, dimensi intelektual, dan dimensi konsekuensional. Berdasarkan Theory of Planned Behavior, religiusitas termasuk dalam aspek sikap yang dapat mempengaruhi minat berwakaf uang. Seseorang dengan tingkat religiusitas tinggi akan bersikap sesuai dengan aturan agama yang dianutnya.

Pada penelitian Hiyanti dkk. (2020) menyimpulkan bahwa religiusitas berpengaruh positif dan signifikan terhadap intensi berwakaf pada CWLS. Penelitian As-Shadiqqy (2019) juga membuktikan bahwa religiusitas akidah memiliki pengaruh yang signifikan terhadap minat berwakaf uang. Sejalan dengan penelitian Osman dkk. (2016) yang menunjukkan bahwa religiusitas menjadi faktor yang signifikan mempengaruhi minat dalam berwakaf uang. Semakin tinggi religiusitas seseorang maka semakin tinggi minatnya dalam berwakaf uang. Berdasarkan uraian tersebut, maka diajukan hipotesis sebagai berikut:

\section{$\boldsymbol{H}_{\boldsymbol{I}}$ : Religiusitas berpengaruh positif terhadap minat berwakaf uang.}

\section{Pengaruh Faktor Literasi Wakaf Dalam Mempengaruhi Minat Berwakaf Uang}

Kementerian Agama Republik Indonesia (2017) menyimpulkan bahwa literasi wakaf adalah kemampuan dalam memahami dan mengolah wakaf yang aman, berkelanjutan, dan bermanfaat. Berdasarkan Theory of Planned Behavior, persepsi kontrol perilaku dapat mempengaruhi minat. Literasi wakaf dapat dianggap sebagai bagian dari persepsi kontrol perilaku karena dapat mempengaruhi perilaku individu dalam membuat keputusan melakukan wakaf uang.

Penelitian Fauziah dan El Ayyubi (2019) menunjukkan bahwa pemahaman wakaf memiliki pengaruh positif terhadap persepsi masyarakat dalam menerima konsep wakaf uang. Sejalan dengan penelitian Baskoroputra (2019) yang menyimpulkan bahwa literasi wakaf uang berpengaruh terhadap persepsi wakaf uang mahasiswa Ekonomi Islam Universitas Brawijaya tahun angkatan 2015-2018. Dalam penelitian Cupian dan Najmi (2020) juga menyimpulkan bahwa literasi wakaf menjadi faktor yang berpengaruh terhadap minat dalam wakaf uang. Dengan demikian, semakin 
baik literasi wakaf seseorang maka minat berwakaf uang akan semakin meningkat. Berdasarkan uraian tersebut, maka diajukan hipotesis sebagai berikut:

\section{$\boldsymbol{H}_{2}$ : Literasi wakaf berpengaruh positif terhadap minat berwakaf uang.}

\section{Peran Akuntabilitas Dalam Memoderasi Pengaruh Religiusitas Terhadap Minat Berwakaf Uang}

Berdasarkan Theory of Planned Behavior, persepsi kontrol perilaku dapat mempengaruhi minat. Akuntabilitas dapat dianggap sebagai bagian dari persepsi kontrol perilaku karena dapat mempengaruhi perilaku individu. Persepsi seseorang terhadap akuntabilitas lembaga wakaf akan mempengaruhi sikapnya dalam membuat keputusan berwakaf uang.

Sejalan dengan penelitian dalam bidang zakat oleh Salmawati dan Fitri (2018), menyimpulkan bahwa akuntabilitas berpengaruh positif terhadap minat muzakki dalam membayar zakat. Dengan demikian, persepsi baik masyarakat tentang akuntabilitas lembaga wakaf akan meningkatkan minat masyarakat dalam berwakaf uang karena eksistensi dan pengelolaan wakaf bergantung pada peran lembaganya (Kasdi, 2014). Akuntabilitas juga diduga bisa memoderasi variabel religiusitas. Dalam hal religiusitas, seseorang yang memiliki tingkat religiusitas tinggi dan juga mengetahui akuntabilitas lembaga wakaf akan merasa semakin yakin untuk melakukan wakaf uang. Berdasarkan uraian tersebut, maka diajukan hipotesis sebagai berikut:

\section{$\boldsymbol{H}_{3}$ : Akuntabilitas dapat memoderasi hubungan antara religiusitas dengan minat berwakaf uang.}

\section{Peran Akuntabilitas Dalam Memoderasi Pengaruh Literasi Wakaf Terhadap Minat Berwakaf Uang}

Nurhayati dkk. (2014) menjelaskan bahwa akuntabilitas merupakan bentuk pertanggungjawaban atas semua aktivitas dan kegiatan organisasi dalam rangka pencapaian tujuan tertentu yang ditampilkan dalam pelaporan keuangan oleh pihak penanggung jawab kepada pemberi amanah atau pihak yang berkepentingan dalam suatu periode. Dalam penelitian bidang zakat Salmawati dan Fitri (2018) menyimpulkan bahwa akuntabilitas berpengaruh positif dan signifikan terhadap minat muzakki membayar zakat di BAZNAS kota Makassar. Dengan demikian, persepsi baik masyarakat tentang akuntabilitas lembaga wakaf akan meningkatkan minat masyarakat dalam berwakaf uang. Akuntabilitas juga diduga bisa memoderasi variabel literasi wakaf. Dalam hal literasi wakaf, saat seseorang memiliki tingkat literasi wakaf yang tinggi dan didukung dengan mengetahui akuntabilitas lembaga wakaf maka minat seseorang tersebut dalam wakaf uang bisa meningkat. Berdasarkan uraian tersebut, maka diajukan hipotesis sebagai berikut:

\section{H: Akuntabilitas dapat memoderasi hubungan antara literasi wakaf dengan minat berwakaf uang.}

\section{METODE PENELITIAN}

Jenis penelitian ini ialah penelitian kuantitatif dengan objek penelitian yang akan diteliti yakni religiusitas, literasi wakaf, akuntabilitas, dan minat berwakaf uang. Populasi pada penelitian ini ialah anggota grup Waqf Center for Indonesian Development Studies (WaCIDS). WaCIDS merupakan sebuah lembaga riset wakaf yang berdiri sejak tahun 2018. Aktivitas WaCIDS meliputi penelitian dan kajian wakaf, kolaborasi dengan pemangku kepentingan sektor perwakafan dan melakukan edukasi serta publikasi kepada masyarakat Indonesia. Kegiatan edukasi dari WaCIDS salah satunya ialah dengan membuat grup diskusi wakaf WaCIDS di Telegram. Anggota grup diskusi tersebut berasal dari berbagai macam kalangan seperti mahasiswa, dosen, dan juga masyarakat umum. Grup kedua ialah grup NoCAFE (Ngobrol Cerdas Ala Fosei) Unsoed yang merupakan sebuah program kerja departemen education dari UKM Fosei (Forum Studi Ekonomi Islam) Fakultas Ekonomi dan Bisnis Universitas Jenderal Soedirman. Anggota dari NoCAFE berasal dari anggota dan pengurus Fosei, dosen, dan mahasiswa umum. 
Penelitian ini menggunakan pendekatan nonprobability sampling dengan metode convenience sampling. Sampel penelitian dihitung menggunakan rumus Slovin sehingga didapat sampel minimal 76 orang. Untuk menjamin validitas dan reliabilitas penelitian, terlebih dahulu dilakukan uji pilot test atas kuesioner. Jenis data yang digunakan dalam penelitian ini ialah data primer dan metode pengumpulan data dilakukan menggunakan kuesioner google form.

\section{Definisi Konseptual dan Operasional Variabel Variabel Dependen}

Variabel dependen yang digunakan dalam penelitian ini ialah minat berwakaf uang. Zusnani (2013) menjelaskan bahwa minat ialah suatu ketertarikan mendalam yang disertai dengan perasaan senang atas suatu hal sehingga menimbulkan tindakan atas dasar keinginan sendiri. Variabel minat berwakaf uang dapat diukur menggunakan indikator-indikator berikut ini (Shaleh \& Wahab, 2004):

1. Faktor dorongan dari dalam (internal)

2. Faktor motif sosial

3. Faktor emosional

\section{Variabel Independen \\ Religiusitas}

Religiusitas dapat dikaitkan dengan nilai-nilai agama yang dianut seseorang. Religiusitas dalam agama Islam meliputi pengetahuan tentang agama (ilmu akidah, akhlak, fiqh, dan lain sebagainya), pengalaman ritual agama (ibadah sholat, puasa, zakat, haji, dan lainnya), moralitas agama, dan sikap sosial keagamaan yang diterapkan. Variabel religiusitas diukur menggunakan indikator-indikator berikut ini (Abou-Youssef dkk., 2011):
1. Pengalaman
2. Ritualistik/Praktik
3. Ideologis/Keyakinan
4. Intelektual
5. Konsekuensional

\section{Literasi Wakaf}

Baskoroputra (2019) menjelaskan bahwa literasi wakaf merupakan kemampuan individu dalam menerima, mengolah, dan memahami informasi wakaf. Literasi wakaf dapat disimpulkan dalam lima verba, yaitu memahami, melibati, menggunakan, menganalisis, dan mengubah teks. Variabel literasi wakaf diukur menggunakan indikator-indikator yang telah ditetapkan oleh BWI yang terbagi menjadi dua tingkatan yaitu:

1. Literasi Pemahaman Wakaf Dasar (Basic Knowledge)

Tingkatan ini mencakup pemahaman masyarakat mengenai unsur-unsur wakaf berupa wakif, benda wakaf, nadzir, ikrar wakaf, dan mauquf 'alaih.

2. Literasi Pemahaman Wakaf Lanjutan (Advance Knowledge)

Tingkatan ini mencakup pemahaman lebih dalam terhadap wakaf seperti wakaf temporer, wakaf uang, dan LKS PWU (Badan Wakaf Indonesia, 2020).

\section{Variabel Moderasi}

Variabel moderasi yang digunakan pada penelitian ini ialah akuntabilitas. Menurut Nurhayati dkk. (2014) akuntabilitas merupakan bentuk pertanggungjawaban atas semua aktivitas dan kegiatan organisasi dalam rangka pencapaian tujuan tertentu yang ditampilkan dalam pelaporan keuangan oleh pihak penanggung jawab kepada pemberi amanah atau pihak yang berkepentingan dalam suatu periode. Akuntabilitas diukur menggunakan indikator-indikator berikut ini (Sholahuddin, 2006):

1. Amanah

2. Profesional

3. Transparansi 


\section{Pengukuran Variabel}

Variabel minat berwakaf uang, religiusitas, literasi wakaf, dan akuntabilitas diukur menggunakan skala likert. Skala likert digunakan untuk mengukur jawaban ke dalam 5 poin skala dengan interval yang sama (Hartono, 2016: 83).

Poin 1 = Sangat Tidak Setuju (STS)

Poin 2 = Tidak Setuju (TS)

Poin $3=$ Cukup Setuju (CS)

Poin $4=$ Setuju (S)

Poin 5 = Sangat Setuju (SS)

\section{Teknik Analisis Data}

Analisis yang digunakan dalam penelitian ini, meliputi statistik deskriptif, uji non response bias, uji asumsi klasik, analisis regresi linier berganda, analisis regresi moderasi, uji koefisien determinasi, uji $\mathrm{F}$ hitung, dan pengujian hipotesis dengan uji statistik t dengan menggunakan aplikasi SPSS version 22.

\section{HASIL DAN PEMBAHASAN}

\section{Uji Kualitas Data (Pilot Test) Uji Validitas}

Uji validitas dilakukan dengan analisis korelasi product moment Pearson dengan taraf signifikansi $\alpha=0,05, \mathrm{n}=31$, dan hasil $\mathrm{r}_{\text {tabel }}$ sebesar $0,355(\mathrm{df}=\mathrm{n}-2)$. Semua item pernyataan tiap variabel menunjukkan hasil $r_{\text {hitum }}$ yang lebih besar dari $r_{\text {abel }}(0,355)$ pada tingkat signifikansi 0,05 sehingga dapat disimpulkan bahwa semua item pernyataan tiap variabel dinyatakan valid.

\section{Uji Reliabilitas}

Hasil Koefisien Cronbach's Alpha untuk variabel religiusitas $\left(\mathrm{X}_{1}\right)$, literasi wakaf $\left(\mathrm{X}_{2}\right)$, akuntabilitas (Z), dan minat berwakaf uang (Y) lebih besar dari nilai Cronbach's Alpha Min $(0,60)$. Hal ini dapat disimpulkan bahwa seluruh instrumen pernyataan dinyatakan reliabel atau andal.

\section{Deskripsi Data Penelitian}

Penelitian ini dilakukan dengan menyebar kuesioner online melalui google form dalam jangka waktu penyebaran 25 Januari 2021 sampai 25 Februari 2021. Kuesioner dibagikan kepada kedua grup dengan jumlah pengembalian kuesioner sebanyak 100 kuesioner, 52 dari anggota WaCIDS dan 48 dari anggota NoCAFE.

\section{Gambaran Umum Responden}

Kuesioner yang telah diterima memiliki informasi karakteristik responden yang digolongkan dalam beberapa aspek seperti jenis kelamin, usia, asal provinsi, pekerjaan, penghasilan, asal grup, dan pernah atau tidaknya berwakaf uang. Responden didominasi oleh responden perempuan sejumlah 60 orang dan responden laki-laki hanya 40 orang. Dilihat dari usia, responden terbanyak ialah responden berusia kurang dari 25 tahun sejumlah 78 orang dan responden paling sedikit dari usia antara 36 sampai 45 tahun yang berjumlah 3 orang. Berdasarkan asal provinsi, Jawa Tengah menjadi provinsi tertinggi dengan responden sebanyak 53 orang dan Provinsi Jambi, Kalimantan Timur, Lampung, NTB, dan Sumatera Selatan menjadi provinsi dengan responden paling rendah yaitu 1 orang.

Responden dilihat dari jenis pekerjaan dapat diketahui bahwa responden didominasi oleh mahasiswa sebanyak 69 orang. Responden dengan pekerjaan sebagai guru dan CPNS menjadi pekerjaan paling sedikit yaitu 1 orang. Distribusi responden jika dilihat berdasarkan penghasilan per bulan menunjukkan bahwa responden mayoritas memiliki penghasilan per bulan sebesar kurang dari atau sama dengan Rp1.000.000, lalu disusul dengan penghasilan Rp1.000.000 sampai Rp3.000.000, lebih dari Rp5.000.000, dan terakhir penghasilan Rp3.000.000 sampai Rp5.000.000. 
Responden berdasarkan asal grup dapat diketahui bahwa responden terbanyak berasal dari grup WaCIDS sebanyak 52 orang dan sisanya berasal dari NoCAFE. Distribusi responden dilihat berdasarkan pernah atau tidak berwakaf uang menunjukkan responden mayoritas belum pernah berwakaf uang.

\section{Statistik Deskriptif}

Analisis statistik deskriptif digunakan untuk mengetahui gambaran umum data penelitian agar lebih mudah dipahami.

Tabel 2 Hasil Statistik Deskriptif

\begin{tabular}{lccccc}
\hline & $\mathrm{N}$ & Minimum & Maximum & Mean & Std. Deviation \\
\hline Religiusitas $\left(\mathrm{X}_{1}\right)$ & 100 & 3,692 & 5,000 & 4,517 & 0,297 \\
LiterasiWakaf $\left(\mathrm{X}_{2}\right)$ & 100 & 2,750 & 5,000 & 4,103 & 0,678 \\
Akuntabilitas $(\mathrm{Z})$ & 100 & 2,818 & 5,000 & 4,186 & 0,654 \\
MinatBerwakafUang $(\mathrm{Y})$ & 100 & 2,857 & 5,000 & 4,284 & 0,643 \\
\hline
\end{tabular}

\section{Uji Non Response Bias}

Pengujian non response bias digunakan untuk mengetahui apakah ada perbedaan pada kedua grup WaCIDS dan NoCAFE karena penelitian bisa dilakukan jika populasi penelitian sama.

Tabel 3 Hasil Uji Non Response Bias

\begin{tabular}{lccccc}
\hline & & \multicolumn{2}{c}{$\begin{array}{c}\text { Levene's Test for } \\
\text { Equality of } \\
\text { Variances }\end{array}$} & \multicolumn{2}{c}{ t-test } \\
\cline { 2 - 6 } & F & Sig. & T & Sig. (2-tailed) \\
\hline Religiusitas & $\begin{array}{c}\text { Equal variances } \\
\text { assumed }\end{array}$ & 0,254 & 0,615 & $-0,126$ & 0,900 \\
\hline Literasi Wakaf & $\begin{array}{c}\text { Equal variances } \\
\text { assumed }\end{array}$ & 0,311 & 0,578 & 3,221 & 0,002 \\
\hline Akuntabilitas & $\begin{array}{c}\text { Equal variances } \\
\text { assumed }\end{array}$ & 0,001 & 0,975 & $-0,432$ & 0,666 \\
\hline $\begin{array}{l}\text { Minat Berwakaf } \\
\text { Uang }\end{array}$ & $\begin{array}{c}\text { Equal variances } \\
\text { assumed }\end{array}$ & 2,367 & 0,127 & 2,586 & 0,011 \\
\hline
\end{tabular}

Berdasarkan tabel 3 dapat dilihat bahwa semua variabel memiliki nilai levene's test dengan signifikansi > 0,05. Hal ini menunjukkan bahwa varian populasi kedua grup WaCIDS dan NoCAFE ialah sama.

\section{Uji Asumsi Klasik}

Uji Normalitas

Nilai Asymp. Sig. (2-tailed) yang diperoleh sebesar 0,161 > 0,05 maka dapat disimpulkan bahwa model regresi berdistribusi normal.

\section{Uji Multikolinearitas}

Nilai tolerance dan VIF pada tiap variabel dalam penelitian ini memiliki nilai masing-masing untuk tolerance $\geq 0,10$ dan VIF $\leq 10$ sehingga tidak ditemukan gejala multikolinearitas dalam penelitian ini.

\section{Uji Heteroskedastisitas}

Nilai signifikansi yang dimiliki tiap variabel $>0,05$ sehingga dapat disimpulkan bahwa tidak ditemukan masalah heteroskedastisitas. 


\section{Uji Linearitas}

Hasil uji linearitas menunjukkan bahwa $\mathrm{X}_{\text {hiums }}^{2} 0,6<\mathrm{X}_{\text {tabel }}^{2} 124,342$, sehingga dapat disimpulkan bahwa model regresi memenuhi asumsi linearitas.

\section{Analisis Regresi Linier Berganda}

Tabel 4 Hasil Uji Regresi Linier Berganda

\begin{tabular}{lccc}
\hline \multicolumn{1}{c}{ Variabel } & Koefisien Regresi & thiums & Sig. \\
\hline Religiusitas $\left(\mathrm{X}_{1}\right)$ & 0,480 & 6,268 & 0,000 \\
Literasi Wakaf $\left(\mathrm{X}_{2}\right)$ & 0,446 & 6,070 & 0,000 \\
\hline Konstanta & 0,016 & & \\
Adjusted R Square & 0,879 & & \\
$\mathrm{~F}_{\text {hitum }}$ & 360,912 & & \\
F sig & 0,000 & & \\
\hline
\end{tabular}

Berdasarkan pada tabel 4, dapat diketahui persamaan regresi linier berganda dengan rumus sebagai berikut:

$$
\mathrm{Y}=0,016+0,480 \mathrm{X}_{1}+0,446 \mathrm{X}_{2}+\mathrm{e}
$$

\section{Analisis Regresi Moderasi}

Tahap I

Tabel 5 Hasil Analisis Regresi Moderasi Pertama

\begin{tabular}{lccc}
\hline \multicolumn{1}{c}{ Variabel } & Koefisien Regresi & thinum & Sig. \\
\hline Religiusitas $\left(\mathrm{X}_{1}\right)$ & 0,807 & 5,934 & 0,000 \\
Akuntabilitas (Z) & $-0,002$ & $-0,680$ & 0,498 \\
$\mathrm{X}$ Z & 0,000 & 0,004 & 0,997 \\
\hline Konstanta & 0,068 & & \\
Adjusted $\boldsymbol{R}$ Square & 0,833 & & \\
$\mathrm{~F}_{\text {hitumg }}$ & 165,532 & & \\
$\mathrm{~F}_{\text {sig }}$ & 0,000 & & \\
\hline
\end{tabular}

Dari pengujian regresi moderasi tahap pertama dapat diperoleh persamaan model regresi moderasi sebagai berikut:

$$
\mathrm{Y}=0,068+0,807 \mathbf{X}_{1}-0,002 \mathrm{Z}+0,000 \mathrm{X}_{\mathbf{1}} \mathbf{Z}+\mathrm{e}
$$

\section{Tahap II}

Tabel 6 Hasil Uji Regresi Moderasi Kedua

\begin{tabular}{lccc}
\multicolumn{1}{c}{ Variabel } & Koefisien Regresi & thimus & Sig. \\
\hline Literasi Wakaf $\left(\mathrm{X}_{2}\right)$ & 0,845 & 7,824 & 0,000 \\
Akuntabilitas $(\mathrm{Z})$ & $-0,002$ & $-0,909$ & 0,366 \\
$\mathrm{X}_{2} \mathrm{Z}$ & $-0,023$ & $-2,620$ & 0,010 \\
\hline Konstanta & 0,171 & & \\
Adjusted $\boldsymbol{R}$ Square & 0,867 & & \\
$\mathrm{~F}_{\text {hitum }}$ & 216,055 & & \\
$\mathrm{~F}$ sig & 0,000 & & \\
\hline
\end{tabular}

Dari pengujian regresi moderasi tahap kedua dapat diperoleh persamaan model regresi moderasi sebagai berikut:

$$
\mathrm{Y}=0,171+0,845 \mathrm{X}_{2}-0,002 \mathrm{Z}-0,023 \mathrm{X}_{2} \mathrm{Z}+\mathrm{e}
$$




\section{Uji Koefisien Determinasi}

Berdasarkan tabel 4, dapat diketahui bahwa nilai Adjusted $R$ Square sebesar 0,879 atau 87,9\% variabel minat berwakaf uang dapat dijelaskan oleh variabel-variabel yang diteliti yaitu religiusitas dan literasi wakaf. Sisanya atau sebesar 12,1\% dijelaskan oleh variabel-variabel lain diluar penelitian.

Berdasarkan tabel 5, dapat diketahui bahwa nilai Adjusted R Square uji regresi moderasi tahap pertama sebesar 0,833 atau 83,3\%, artinya variabel minat berwakaf uang dapat dijelaskan oleh variabel religiusitas, akuntabilitas, dan interaksi religiusitas dengan akuntabilitas. Sisanya atau sebesar 16,7\% dijelaskan oleh variabel-variabel lain yang tidak diteliti.

Berdasarkan tabel 6, dapat diketahui nilai Adjusted R Square uji regresi moderasi tahap kedua sebesar 0,867 atau $86,7 \%$. Hal ini memiliki arti bahwa variabel minat berwakaf uang dapat dijelaskan oleh variabel literasi wakaf, akuntabilitas, dan interaksi literasi wakaf dengan akuntabilitas. Sisanya sebesar 13,3\% dijelaskan oleh variabel lain di luar penelitian.

\section{Uji F Hitung}

Berdasarkan tabel 4, dapat diketahui bahwa $\mathbf{F}_{\text {hitumg }}>\mathbf{F}_{\text {takel }}$ (360,912 > 3,091) dan Sig. $<0,05$ masuk dalam kriteria dan dapat disimpulkan bahwa model regresi telah masuk dalam kriteria cocok (fit).

Berdasarkan tabel 5, dapat dilihat bahwa nilai $\mathbf{F}_{\text {hitums }}>\mathbf{F}_{\text {tabel }}(165,532>2,700)$ dan Sig. $<0,05$, maka dapat disimpulkan bahwa model regresi dapat digunakan untuk menjelaskan variabel dependen atau dapat dikatakan bahwa religiusitas, akuntabilitas, dan interaksi religiusitas dengan akuntabilitas secara bersama-sama berpengaruh terhadap minat berwakaf uang.

Berdasarkan tabel 6, dapat diketahui bahwa nilai $\mathbf{F}_{\text {hitum }}>\mathbf{F}_{\text {abel }}(216,055>2,700)$ dan Sig: $<0,05$, maka dapat dikatakan bahwa model regresi dapat digunakan untuk memprediksi variabel dependen atau dapat dikatakan bahwa literasi wakaf, akuntabilitas, dan interaksi literasi wakaf dengan akuntabilitas secara bersama-sama berpengaruh terhadap minat berwakaf uang.

\section{Pengujian Hipotesis}

Pengujian hipotesis pada penelitian ini menggunakan uji t. Suliyanto (2011: 45) menjelaskan bahwa nilai t hitung digunakan untuk menguji pengaruh variabel independen terhadap variabel dependen secara parsial dengan asumsi variabel lain adalah konstan.

1. Hasil pengujian hipotesis pertama menunjukkan bahwa variabel religiusitas memiliki nilai thinumg $(6,268)>$ nilai takel $(1,661)$ dan nilai signifikansi sebesar $0,000<0,005$ dengan koefisien regresi 0,480. Hal ini dapat disimpulkan bahwa religiusitas memiliki pengaruh positif terhadap minat berwakaf uang sehingga hipotesis pertama $\left(\mathrm{H}_{1}\right)$ yang menyatakan religiusitas berpengaruh positif terhadap minat berwakaf uang diterima.

2. Hasil pengujian hipotesis kedua menunjukkan bahwa variabel literasi wakaf memiliki nilai thinugs $(6,070)>$ nilai taber $(1,661)$ dan nilai signifikansi sebesar $0,000<0,005$ dengan koefisien regresi 0,446. Hal ini dapat disimpulkan bahwa literasi wakaf memiliki pengaruh positif terhadap minat berwakaf uang sehingga hipotesis kedua $\left(\mathrm{H}_{2}\right)$ yang menyatakan literasi wakaf berpengaruh positif terhadap minat berwakaf uang diterima.

3. Hasil pengujian hipotesis ketiga menunjukkan bahwa variabel interaksi antara religiusitas dan akuntabilitas memiliki koefisien regresi sebesar $0,000\left(\beta_{3}=0\right)$ dengan nilai thitumg $(0,004)<$ nilai takel $(1,661)$ dan nilai signifikansi $0,997(>0,05)$. Variabel $X_{1} Z$ yang merupakan interaksi antara religiusitas dan akuntabilitas tidak signifikan, sehingga dapat disimpulkan bahwa akuntabilitas tidak dapat memoderasi hubungan religiusitas terhadap minat berwakaf uang atau hipotesis ketiga $\left(\mathrm{H}_{3}\right)$ yang diajukan ditolak.

4. Hasil pengujian hipotesis keempat menunjukkan bahwa variabel interaksi antara literasi wakaf dengan akuntabilitas memiliki koefisien regresi sebesar $-0,023\left(\beta_{3} \neq 0\right)$ dengan nilai thimung $(-2,620)$

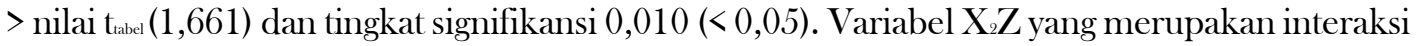
antara literasi wakaf dengan akuntabilitas ternyata signifikan, sehingga dapat disimpulkan bahwa akuntabilitas dapat memoderasi hubungan literasi wakaf terhadap minat berwakaf uang atau hipotesis keempat $\left(\mathrm{H}_{4}\right)$ yang diajukan diterima. 


\section{Pembahasan}

\section{Hipotesis 1}

Hipotesis pertama diajukan menyatakan bahwa religiusitas berpengaruh positif terhadap minat berwakaf uang dan berdasarkan hasil penelitian hipotesis pertama ini diterima. Hal ini memiliki arti bahwa religiusitas memiliki pengaruh positif terhadap minat berwakaf uang. Sejalan dengan penelitian Hiyanti dkk. (2020), As-Shadiqqy (2019), Osman dkk. (2016) yang menyatakan bahwa religiusitas berpengaruh positif terhadap minat berwakaf uang.

Dilihat dari Theory of Planned Behavior, religiusitas termasuk dalam aspek sikap yaitu perasaan positif atau negatif individu dalam melakukan suatu perilaku. Aspek sikap pada religiusitas ini menimbulkan keyakinan pada individu dalam menjalankan perintah agamanya. Sehingga seseorang dengan tingkat religiusitas tinggi akan bersikap sesuai dengan aturan agama yang dianutnya.

Seseorang yang memiliki tingkat religiusitas tinggi akan menyadari dan melaksanakan perintahperintah agama baik yang bersifat wajib maupun sunnah seperti wakaf. Seseorang dengan religiusitas yang tinggi akan menyadari bahwa pahala wakaf sangat besar sehingga tertarik untuk melakukannya. Hal ini dibuktikan dengan hasil penyebaran kuesioner pada variabel minat pernyataan nomor 34 (Saya tertarik berwakaf uang karena mengharap pahala dari Allah SWT) yang memperoleh skor rata-rata 4,48. Kesadaran akan pahala wakaf dan jenis wakaf uang yang tanpa batasan nominal mampu menarik minat untuk berwakaf uang.

\section{Hipotesis 2}

Hipotesis kedua diajukan menyatakan bahwa literasi wakaf berpengaruh positif terhadap minat berwakaf uang dan berdasarkan hasil penelitian hipotesis kedua ini diterima. Hal ini dapat disimpulkan bahwa literasi wakaf memiliki pengaruh positif terhadap minat berwakaf uang. Sejalan dengan penelitian Hiyanti dkk. (2020), Baskoroputra (2019), Mokthar (2016) yang menyatakan bahwa literasi wakaf berpengaruh positif terhadap minat berwakaf uang.

Berdasarkan Theory of Planned Behavior, literasi wakaf dapat dianggap sebagai bagian dari persepsi kontrol perilaku. Persepsi kontrol perilaku mengacu pada persepsi individu tentang kemampuan mereka dalam melakukan suatu perilaku Osman dkk. (2016). Literasi wakaf yang dimiliki individu dapat mempengaruhi perilaku individu dalam membuat keputusan melakukan wakaf uang sehingga semakin tinggi literasi wakaf maka akan meningkatkan minat berwakaf uang.

Seseorang yang mengetahui wakaf uang dan konsep pengelolaannya akan memiliki minat yang tinggi terhadap wakaf uang. Hal ini dijelaskan dari hasil penyebaran kuesioner pernyataan nomor 20 mengenai pengelolaan wakaf uang yang mendapat skor jawaban rata-rata 4,03. Pernyataan nomor 36 mengenai keinginan menyukseskan wakaf uang di Indonesia yang mendapat skor ratarata 4,43. Sehingga dapat disimpulkan bahwa tingkat literasi wakaf yang tinggi akan membuat individu memiliki minat yang tinggi pada wakaf uang.

\section{Hipotesis 3}

Pengujian hipotesis ketiga mengenai akuntabilitas dapat memoderasi hubungan religiusitas terhadap minat berwakaf uang. Hasil penelitian menyimpulkan bahwa hipotesis ketiga ini ditolak atau akuntabilitas tidak dapat memoderasi hubungan religiusitas terhadap minat berwakaf uang. Hal ini sejalan dengan penelitian dalam bidang zakat oleh Yuliafitri \& Khoiriyah (2016) yang menyatakan bahwa akuntabilitas tidak berpengaruh terhadap loyalitas muzakki.

Dalam hipotesis yang dibangun, akuntabilitas sebagai faktor eksternal dari minat dianggap mampu memoderasi hubungan religiusitas terhadap minat berwakaf uang. Akuntabilitas dalam Theory of Planned Behavior dapat dianggap sebagai bagian dari persepsi kontrol perilaku karena dapat mempengaruhi perilaku individu. Persepsi seseorang terhadap akuntabilitas lembaga wakaf akan mempengaruhi sikapnya dalam membuat keputusan berwakaf uang. Ketika seseorang dengan religiusitas yang tinggi dan memiliki persepsi yang baik terhadap akuntabilitas lembaga wakaf maka minat berwakaf uang orang tersebut akan meningkat. Namun hal ini tidak sejalan dengan hasil penelitian atau hipotesis ditolak. 
Berdasarkan hasil penelitian, akuntabilitas lembaga wakaf tidak dapat memoderasi hubungan religiusitas terhadap minat berwakaf uang. Hal ini dikarenakan religiusitas merupakan tindakan yang sumbernya berasal langsung atau tidak langsung kepada Nash (Jalaludin, 2001: 89). Pada masyarakat secara umum, religiusitas dianggap hanya sebagai hubungan hablumminallah sehingga faktor lain seperti persepsi akuntabilitas lembaga wakaf tidak dapat mempengaruhi keputusan berwakaf uang. Namun demikian akuntabilitas lembaga wakaf tetap penting karena lembaga wakaf harus memiliki akuntabilitas kepada Allah dan akuntabilitas kepada manusia dengan memberikan pelaporan secara berkala.

\section{Hipotesis 4}

Pengujian hipotesis keempat mengenai akuntabilitas dapat memoderasi hubungan literasi wakaf terhadap minat berwakaf uang. Hasil penelitian menyimpulkan bahwa hipotesis keempat ini diterima atau akuntabilitas dapat memoderasi hubungan literasi wakaf terhadap minat berwakaf uang. Dilihat dari arah koefisien regresi, akuntabilitas memberikan dampak moderasi melemahkan hubungan literasi wakaf terhadap minat berwakaf uang. Hal ini sejalan dengan hasil penelitian Istikhomah dan Asrori (2019) yang menyatakan bahwa akuntabilitas OPZ berpengaruh secara negatif terhadap kepercayaan muzakki pada lembaga pengelola zakat.

Berdasarkan Theory of Planned Behavior, akuntabilitas dapat dianggap sebagai bagian dari persepsi kontrol perilaku karena dapat mempengaruhi perilaku individu. Persepsi seseorang terhadap akuntabilitas lembaga wakaf dapat mempengaruhi minat berwakaf uang. Akuntabilitas sebagai faktor eksternal dari minat dianggap mampu memoderasi hubungan literasi wakaf terhadap minat berwakaf uang.

Akuntabilitas dapat memoderasi hubungan literasi wakaf terhadap minat berwakaf uang. Seseorang yang mengetahui konsep dan pengelolaan wakaf, serta memiliki persepsi tertentu terhadap akuntabilitas lembaga wakaf akan membuat keputusan yang berbeda dibandingkan dengan yang tidak memiliki persepsi akuntabilitas lembaga wakaf. Pada penelitian ini akuntabilitas memiliki dampak moderasi melemahkan hubungan antara variabel literasi wakaf terhadap minat berwakaf uang. Hal ini dikarenakan semakin baik tingkat literasi wakaf seseorang, maka akuntabilitas lembaga wakaf dapat dinilai ketaatannya pada peraturan dan standar yang berlaku. Dengan demikian, tingginya tingkat literasi seseorang (wakif) dapat menurunkan minat berwakaf uang bila lembaga wakaf tersebut kurang memperhatikan tingkat ketaatannya terhadap peraturan dan standar yang berlaku sebagai media akuntabilitasnya.

\section{KETERBATASAN PENELITIAN}

Penelitian ini memiliki beberapa keterbatasan, yaitu: (1) Penelitian ini dilakukan pada dua grup diskusi wakaf yaitu WaCIDS dan NoCAFE yang anggotanya sudah mengenal wakaf, (2) Penelitian ini hanya berfokus pada wakaf uang. Berdasarkan keterbatasan tersebut, penelitian selanjutnya diharapkan dapat meneliti minat berwakaf uang pada masyarakat umum sehingga bisa merepresentasikan minat berwakaf uang secara umum. Dan penelitian selanjutnya diharapkan dapat meneliti minat berwakaf jenis lain seperti cash waqf link sukuk, wakaf hewan, dan lainnya.

\section{KESIMPULAN}

Berdasarkan hasil penelitian dan pembahasan yang telah dijabarkan, maka dapat ditarik kesimpulan sebagai berikut: (1) Religiusitas berpengaruh positif terhadap minat berwakaf uang, (2) Literasi wakaf berpengaruh positif terhadap minat berwakaf uang, (3) Akuntabilitas tidak dapat memoderasi hubungan antara religiusitas dengan minat berwakaf uang, (4) Akuntabilitas dapat memoderasi hubungan antara literasi wakaf dengan minat berwakaf uang. Pada penelitian ini variabel akuntabilitas dapat melemahkan hubungan literasi wakaf terhadap minat berwakaf uang. 
Implikasi dari penelitian ini ialah sebagai berikut: (1) Penelitian ini dapat digunakan sebagai referensi penelitian serupa selanjutnya dan dapat digunakan untuk mempertimbangkan variabel penelitian yang akan dilakukan. Selain itu, penelitian ini juga dapat dijadikan referensi tambahan mengenai penggunaan Theory of Planned Behavior dalam bidang akuntansi syariah khususnya wakaf uang. (2) Bagi stakeholders wakaf uang yaitu BWI, Kemenag, LKS PWU, dan lembaga wakaf sebaiknya memperhatikan faktor-faktor yang mempengaruhi minat berwakaf uang seperti religiusitas, literasi wakaf, dan akuntabilitas. (3) Pemerintah dapat ikut meningkatkan minat wakaf uang dengan membuat Gerakan Nasional Wakaf Uang (GNWU) bukan hanya pada pegawai Kemenag namun pada instansi lain. Pemerintah juga dapat melakukan pelaporan yang terpercaya atas pengelolaan GNWU. (4) BWI dapat lebih menggencarkan gerakan pengenalan wakaf uang kepada generasi milenial dengan cara mengunjungi kampus-kampus, membuat seminar wakaf, dan sosialisasi melalui sosial media. (5) LKS PWU selaku penghimpun dan pengumpul dana wakaf uang harus ikut mengenalkan wakaf uang kepada para nasabahnya. Hal tersebut akan dapat meningkatkan minat nasabah masing-masing LKS PWU terhadap wakaf uang. (6) Lembaga wakaf sebagai pihak yang bertanggung jawab mengelola dana wakaf uang dapat meningkatkan kualitas dan akuntabilitasnya. Lembaga wakaf harus mengelola dana wakaf uang dengan baik sehingga bisa disalurkan secara tepat. (7) Komunitas pegiat wakaf dan komunitas rohani Islam tiap kampus dapat menciptakan lingkungan yang religius dan dapat melakukan pengenalan wakaf uang bukan hanya ke anggotanya tetapi juga kepada masyarakat sekitar.

\section{DAFTAR PUSTAKA}

Abou-Youssef, M., Kortam, W., Abou-Aish, E. \& El-Bassiouny, N. (2011). Measuring IslamicDriven Buyer Behavioral Implications: A Proposed Market-Minded Religiosity Scale. Journal of American Science, 7(8), 788-801.

Ajzen, I. (1991). The theory of planned behavior. Organizational Behavior and Human Decision Processes, 50(2), 179-211. https://doi.org/10.1016/0749-5978(91)90020-t

Amalia, A. N., \& Puspita, P. (2018). Minat masyarakat Jakarta dalam berwakaf uang pada lembaga wakaf. Syi ar Iqtishadi: Journal of Islamic Economics, Finance and Banking, 2(2), 1-19. https://doi.org/10.35448/jiec.v2i2.4382

Assagaf, M. A. (2016). Pengaruh akuntabilitas dan transparansi pengelolaan zakat terhadap minat muzakki membayar zakat. Skripsi. UIN Alauddin Makassar.

As-Shadiqqy, M. (2019). Pengaruh pendapatan, religiusitas, jarak lokasi, tingkat pendidikan dan akses informasi terhadap minat masyarakat untuk berwakaf uang di badan wakaf uang tunai MUI DIY. Panangkaran: Jurnal Penelitian Agama dan Masyarakat, 2(2), 249-269. https://doi.org/10.14421/panangkaran.2018.0202-05

Badan Pusat Statistik. (2020). Persentase Penduduk Miskin Maret 2020 naik menjadi 9,78 persen. Diakses dari https://www.bps.go.id/pressrelease/2020/07/15/1744/persentase-pendudukmiskin-maret-2020-naik-menjadi-9-78-persen.html

Badan Wakaf Indonesia. (2020). Laporan Hasil Survey Indeks Literasi Wakaf 2020. Diakses dari https://www.bwi.go.id/4849/2020/05/20/laporan-hasil-survev-indeks-literasi-wakaf-nasionaltahun-2020/

Badan Wakaf Indonesia. (2020). Pers Release Public Expose Indeks Literasi Zakat dan Wakaf. Diakses dari https:/www.bwi.go.id/4863/2020/05/19/pemetaan-tingkat-literasi-zakat-danwakaf-nasional-pendekatan-indeks-literasi-zakat-dan-wakaf/

Badan Wakaf Indonesia. (2021). Laporan dari 92 nazhir wakaf uang terdaftar. Diakses dari https://www.bwi.go.id/6065/2021/02/24/update-daftar-nazhir-wakaf-uang-februari-2021/

Baskoroputra, G. F. (2019). Analisa tingkat literasi wakaf uang dan pengaruhnya pada persepsi wakaf uang (Studi kasus pada mahasiswa Ekonomi Islam Universitas Brawijaya). Jurnal Ilmiah
Mahasiswa
FEB,
$7(2)$
$1-13$.
Diakses
dari

https://jimfeb.ub.ac.id/index.php/jimfeb/article/view/5739 
Cupian, C., \& Najmi, N. (2020). Analisis faktor-faktor yang memengaruhi persepsi masyarakat terhadap wakaf uang di kota Bandung. Jurnal Ilmiah Ekonomi Islam, 6(2), 151-162. https://doi.org/10.29040/jiei.v6i2.1045

Fauziah, S., \& El Ayyubi, S. (2019). Faktor-faktor yang memengaruhi persepsi wakif terhadap wakaf uang di Kota Bogor. Al-Muzara'ah, 7(1), 19-31. https://doi.org/10.29244/jam.7.1.19-31

Hiyanti, H., Afiyana, I., \& Fazriah, S. (2020). Potensi dan realisasi wakaf uang di Indonesia Tahun 2014-2018. Jurnal Ilmiah MEA (Manajemen, Ekonomi, \& Akuntansi), 4(1), 77-84. Diakses dari http://journal.stiemb.ac.id/index.php/mea/article/view/207

Ibrahim, S.H.M. (2000). The Need for Islamic Accounting: Perception of Malaysian Muslims Accountants and Academicians on The Objectives and Characteristics of Islamic Accounting. Thesis. University Of Dundee.

Ihsan, H., \& Ibrahim, H.M.S. (2011). WAQF accounting and management in Indonesian WAQF institutions. Humanomics, 27(4), 252-269. https://doi.org/10.1108/08288661111181305

Istikhomah, D., \& Asrori, A. (2019). Pengaruh literasi terhadap kepercayaan muzaki pada lembaga pengelola zakat dengan akuntabilitas dan transparansi sebagai variabel intervening. Economic Education Analysis Journal, 8(1), 95-109. Diakses dari https://journal.unnes.ac.id/sju/index.php/eeaj/article/view/29763

Jalaludin. (2001). Psikologi Agama. Jakarta: Raja Grafindo Persada.

Kasdi, A. (2014). Peran nadzir dalam pengembangan wakaf. Jurnal Zakat dan Wakaf (ZISWAF), 1(2), 213-226. Diakses dari https://journal.iainkudus.ac.id/index.php/Ziswaf/article/view/1483

Kementerian Agama Republik Indonesia. (2017). Buka Seminar Wakaf Internasional, Dirjen:
Umat
Harus
Tingkatkan
Literasi
Wakaf?.
Diakses
dari

https://bimasislam.kemenag.go.id/post/berita/buka-seminar-wakaf-internasional-dirjen-umatharus-tingkatkan-literasi-wakaf-10

Kementerian Keuangan Republik Indonesia. (2019). Strategi Pengembangan Wakaf Uang dalam Rangka Pendalaman Pasar Keuangan Syariah. Diakses dari https://fiskal.kemenkeu.go.id/kajian/2019/12/20/155813610857736-strategi-pengembanganwakaf-uang-dalam-rangka-pendalaman-pasar-keuangan-syariah

Mardiasmo. (2009). Akuntansi sektor publik. Yogyakarta: Andi.

Mokthar, M. Z. (2016). Perceptions of Universiti Sains Malaysia Muslim Staff on Factors Influencing their Intention to Perform Cash Waqf. Journal of Islamic Studies and Culture, 4(2), 101-109. https://doi.org/10.15640/jisc.v4n2a11

Munadiyan, A. E. (2020). Wakaf Solusi Pengentasan Kemiskinan Pascapandemi Covid-19. Diakses dari https://www.republika.co.id/berita/qaos2b313/wakaf-solusi-pengentasan-kemiskinanpascapandemi-covid-19

Nurhayati, N., Fadilah, S., Iss, A., \& Oktaroza, M. L. (2014). Pengaruh Kualitas Informasi Akuntansi, Akuntabilitas, dan Transparansi Pelaporan Keuangan Terhadap Tingkat Penerimaan Dana Zakat Pda Badan Amil Zakat (BAZ) di Jawa Barat. Prosiding Seminar Nasional Penelitian dan PKM Sosial, Ekonomi, dan Humaniora. Diakses dari http://proceeding.unisba.ac.id/index.php/sosial/article/view/343

Nurhayati, S., \& Abdullah, W. (2016). Akuntansi Syariah di Indonesia. Jakarta: Salemba Empat.

Nurhayati, S., \& Abdullah, W. (2019). Akuntansi Syariah di Indonesia (Edisi 5). Jakarta: Salemba Empat.

Osman, A. F., Mohammed, M. O., \& Fadzil, A. (2016). Factor Influencing Cash Waqf Giving Behavior: A Revised Theory of Planned Behavior. Journal Of Global Business and Social Entrepreneurship (GBSE), 1, 12-25. Diakses dari http://gbse.com.mv/isimarch16/GBSE\%201(2)\%2012-25\%20(March\%202016).pdf

Pew Researcher Center. (2020). Global Religious Futures. Diakses dari Pew Researcher Center: http://www.globalreligiousfutures.org/countries/indonesia/religious_demography\#/?affiliations _religion_id $=0 \&$ affiliations_year $=2020$

Prasinanda, R. P., \& Widiastuti, T. (2019). Peran Nazhir Dalam Mengelola Hasil Wakaf Uang Pada Badan Wakaf Indonesia Jawa Timur. Jurnal Ekonomi Syariah Teori dan Terapan, 6(12), 2553-2567. https://doi.org/10.20473/vol6iss201912pp2553-2567 
Rizal, H., \& Amin, H. (2017). Perceived ihsan, Islamic egalitarianism and Islamic religiosity towards charitable giving of cash waqf. Journal of Islamic Marketing, 8(4), 669-685. https://doi.org/10.1108/jima-05-2015-0037

Salmawati, \& Fitri, M. (2018). Pengaruh Tingkat Pendapatan, Religiusitas, Akuntabilitas, dan Kualitas Pelayanan Terhadap Minat Muzakki Membayar Zakat Di Baitul Mal Kota Banda Aceh. Jurnal Ilmiah Mahasiswa Ekonomi Akuntansi (JIMEKA), 3(1), 54-66. Diakses dari http://jim.unsviah.ac.id/EKA/article/view/9736

Shaleh, A. R., \& Wahab, M. A. (2004). Psikologi Suatu Pengantar Dalam Perspektif Islam. Jakarta: Prenada Media.

Sholahuddin. (2006). Ekonomi Islam. Surakarta: Muhammadiyah University Press.

Suliyanto, S. (2011). Ekonometrika Terapan: Teori dan Aplikasi dengan SPSS. Yogyakarta: Andi.

Winahyu, A. I. (2019). BWI Potensi Wakaf Indonesia Rp 77 Triliun Setahun. Diakses dari https://mediaindonesia.com/ekonomi/235549/bwi-potensi-wakaf-indonesia-rp77-triliunsetahun

Yuliafitri, I., \& Khoiriyah, A. N. (2016). Pengaruh Kepuasan Muzakki, Transparansi, dan Akuntabilitas Pada Lembaga Amil Zakat Terhadap Loyalitas Muzakki (Studi Pada LAZ Rumah Zakat). Islamiconomic: Jurnal Ekonomi Islam, 7(2), 205-218. https://doi.org/10.32678/ijei.v7i2.41

Zusnani, I. (2013). Manajemen Pendidikan Berbasis Karakter Bangsa. Yogyakarta: Platinum. 